Behavior and Social Issues, 24, 141-163 (2015). (C) Tete Kobla Agbota, Ingunn Sandaker, \& Gunnar Ree. Readers of this article may copy it without the copyright owner's permission, if the author and publisher are acknowledged in the copy and the copy is used for educational, not-for-profit purposes. doi:

10.5210/bsi.v.24i0.5864

\title{
Verbal Operants of Corruption: A STUdy of Avoidance IN CORRUPTION BEHAVIOR
}

\author{
Tete Kobla Agbota ${ }^{1}$ \\ Ingunn Sandaker \\ Gunnar Ree
}

Oslo and Akershus University College of Applied Sciences

Faculty of Health Sciences, Department of Behavioral Science

Oslo - Norway

\begin{abstract}
Corruption is illegal and universally shameful. Persons who engage in corrupt practices tend to be discreet. This study offers an analysis of metaphors in corruption language based on positive and avoidance contingencies of reinforcement. Our data show that parties to corrupt practices use expressions that accentuate this discreet behavior, whether demanding or offering bribes. Our findings indicate that corruption language can be topographically similar to other verbal utterances, but functionally different when understood in context. Both officials and clients use metaphors to avoid prosecution and social embarrassment. The verbal behavior of the public servant is positively reinforced because he gets a bribe, and the verbal behavior of the client is positively reinforced because he/she receives service or favorable answer to application promptly. However, the payment of money denotes punishment.

KEYWORDS: avoidance; corruption; Ghana, corruption; metaphors, disguised mands, positive reinforcement
\end{abstract}

"What do 'beans for the kids' in Kinshasa, 'a glass of wine' in Paris and 'little carps' in Prague have in common"? According to Henig (2013), the phrases do not only indicate something about local cuisines, but they are also euphemisms for bribes (p. 1). The use of corruption language is a common phenomenon associated with the demand and supply sides of corrupt behavior (Vian, Gryboski, Sinoimeri, \& Clifford, 2004). Quite a number of works have discussed the nature and role of corruption language in Africa (Adjei, 2009; Hasty, 2005; Polzenhagen \& Wolf, 2007). In this article, we explore language associated with soliciting or offering bribes in Ghana. Corruption language is a figurative language of metaphors and euphemisms (as when a speaker uses a disguised mand) associated with soliciting and offering a

\footnotetext{
${ }^{1}$ Author Note: We extend our appreciations to the Ph.D. Group of the Cultural Selection and Behavioral Economics Lab of the Department of Behavioral Science for their feedbacks on earlier versions of the paper. We thank Michael F. Valdez for proofreading and comments. We also wish to thank the anonymous reviewers for their critical, constructive and supportive comments. This article was presented as a paper at ABAI Congress in San Antonio, May 22-26, 2015, under the theme Verbal Operants of Corruption.

Corresponding Author: Tete Kobla Agbota, Oslo and Akershus College of Applied Sciences Faculty of Health Sciences, Department of Behavioral Science, Oslo - Norway. Email: tetekobla.agbota@hioa.no
} 
bribe. According to Wittink (2011), figurative terminologies are common, frequent and pervasive in our verbal behavior. A metaphor (a derivative of the Greek word "metapherein" meaning to transfer), is a "figure of speech in which a word or phrase is applied to an object or action to which it is not literally applicable" (Metaphor, n.d.). A metaphor describes one thing in terms of another (Knowles \& Moon, 2006). A synecdoche is a form of metaphor in which a part of a thing signifies the whole or the whole signifies the part. For example, in the Lord's Prayer "Give us this day our daily bread," bread will mean food taken each day (Cuddon \& Preston, 1998, p. 890). A metonymy, also a form of metaphor, uses the name of an attribute or a thing to substitute the thing itself. The examples normally given are "the Stage" for theatrical profession, "the Crown" for the Monarchy and the "the Bench" for the judiciary, to mention a few (Cuddon \& Preston, 1998, p. 507). The term euphemism also originates from the Greek words "eu" meaning well and "pheme" meaning speaking. It means a "mild or indirect word or expression substituted for one considered to be too harsh or blunt when referring to something unpleasant or embarrassing" (Euphemism, n.d.). We use metaphors and euphemisms interchangeably in this article.

Corruption language is common, and it exists in almost all countries (Patrick, 2013; Vian et al., 2004). There are several studies of metaphors associated with corruption from linguistic and sociological perspectives. Polzenhagen and Wolf (2007) observed that "metaphors are euphemistic; they are drawn upon in the conceptualization of corruption to hide the illicit nature of corrupt practices" (p. 125). Anand, Ashforth, and Joshi (2004), stated that "One of the most important factors that abet rationalizing and socializing is the use of euphemistic language, which enables individuals engaging in corruption to describe their acts in ways that make them appear inoffensive" (p. 47). Though the above observations may be accurate, they offer no systematic explanation for this behavior. Our article employs a behavior analytic approach to explaining the use of figurative language when soliciting or offering bribes.

\section{Verbal Behavior and Metaphor}

We reviewed four random volumes of The Analysis of Verbal Behavior (volumes 18, 19, 28 and 29) for the word metaphor. The word appeared once, in a commentary on book reviews by Hayes, Barnes-Holmes, and Roche (2003). Luke (2003) did not use the term even once in her article that examined poetic literature using B. F. Skinner's theoretical framework on verbal behavior. The review may indicate that the subject of metaphor does not command much interest from researchers studying verbal behavior. However, according to Skinner (1957), the context of a speaker's utterances is essential in understanding behavior. A verbal behavior is more explainable scientifically with a functional analysis, because consequences mediated by other people control it (the behavior). A functional analysis of behavior investigates the functional relations between behavior and environmental variables, and makes it possible to establish the antecedents and the consequences that influence behavior (Baum, 2005; Catania, 2013). Skinner (1957) argued that "an adequate account of verbal behavior needs cover only as much of the behavior of the listener as is needed to explain the behavior of the speaker," for a functional analysis of a verbal behavior (Skinner, 1957, p. 2).

The analysis Skinner offered was different in principle from the linguistic understanding, which was gaining ground among researchers on language represented by the works of (Chomsky, 1967, 1986). Skinner proposed what he called an "exercise in interpretation rather than a quantitative extrapolation of rigorous experimental results" (Skinner, 1957, p. 11). Skinner 


\section{VERBAL OPERANTS OF CORRUPTION}

saw verbal behavior as a function of biological properties of the organism, the organisms' learning history, and current stimulus conditions. Verbal behavior is like any other behavior (with the additional restrictions outlined in the definition below) in that it may occur publicly (for instance speaking) or covertly (thinking). How we talk about the important issues in our lives is a matter of reinforcement contingencies. Contingencies of verbal behavior shape and maintain our social behavior in powerful ways, and they are important tools of cultural selection (Baum, 2000). Verbal behavior by definition is operant behavior; other persons (listeners) mediate the reinforcers for the operant behavior, and these listeners have acquired their reinforcer-mediating behavior in a specific verbal community (Skinner, 1957).

Skinner's interpretation explicitly rejects traditional linguistic and philosophical notions of meaning or reference, arguing that discussions about definitions are bound to be either circular or infinitely regressive (Skinner, 1945). In line with the general epistemological tenets of radical behaviorism, Skinner argues that the meaning of a word or a sentence lies in the controlling variables; the term "means" whatever situation or event in which the verbal community trains its members to reinforce its occurrence. There cannot be any arguments about what a word really means when one accepts topographical differences in verbal episodes as products of social reinforcement contingencies and evolution, rather than tied to das Ding an sich (Ding-an-sich, n.d.). If the verbal community reinforces a verbal response, the verbal response is "understood." In any particular culture, an important part of understanding lies in being able to react appropriately to the metaphors of that verbal community.

Skinner's description of possible functional categories, or verbal operants, includes a description of the tact, and of how metaphorical extension of tacts can occur. The tact is "a verbal operant in which a response of given form is evoked (or at least strengthened) by a particular object or event or property of an object or event" (Skinner, 1957, p. 81-82). Control by a prior stimulus is characteristic of the basic functional category of the tact. Skinner explicitly rejects making the tact a synonym to a name or meaning; the important point is the controlling relation, and the reinforcement for correct tacting is generally in the form of generalized conditioned reinforcers. Skinners' analysis also includes the extended tact, recognizing that stimulus control may be imprecise: "If a response is reinforced upon a given occasion or class of occasions, any feature of that occasion or common to that class appears to gain some measure of control" (Skinner, 1957, p. 91). It allows for expansion of the stimulus classes that controls a tact, and the term extended tact covers various forms. Saying "car" to refer to a new model that you have never seen before can be a generic extension; speaking of "the Government" when you refer to only one representative of the sitting regime can be a metonymical extension. The metaphorical extension of tacts is of special interest in this paper. This kind of extension occurs when "the control exercised by the properties of the stimulus which, though present at reinforcement, do not enter into the contingency respected by the verbal community" (Skinner, 1957, p. 92).

Skinner goes on to exemplify various ways in which metaphorical extensions of tacts can take place. One main point regarding the metaphorical extensions in Verbal Behavior is that, when a speaker utters a metaphor, the listener understands it, in the sense that he reinforces the verbal response. Metaphors may hide the contingencies of reinforcement from listeners unfamiliar with the social contingencies in effect. Being "in the know" implies understanding a slang expression, which is often metaphorical. It means understanding the real contingencies governing a statement that is ambiguous, or one that is topographically unambiguous, but still it is not to be taken literally. If one is a member of a verbal community, one reinforces them 
according to the standards of the verbal community because one has learnt the behavior of reinforcing metaphoric verbal behavior from the members of the culture, and this is especially relevant for corruption behavior, with the metaphors having the function of softened or disguised mands (Skinner, 1957, p. 41). Multiple contingencies control complex human behavior, and it often produces both possible reinforcers and possible punishing events as consequences:

most verbal behavior is in fact under the multiple control of variables that characterize more than one verbal operant. The motivational variables that define the mands frequently enter into these multiply-controlled relations, and may serve to reduce the correspondence between what the speaker sees, hears, or feels, and what the speaker actually reports. Throughout the remainder of Verbal Behavior, Skinner makes clear that the controlling variables for the mands are ubiquitous in both simple and complex verbal behavior. In other words, the behavior of a speaker cannot be analyzed solely in terms of discriminative stimuli in the speaker's environment; it is complete only when motivational variables are also taken into account. (Petursdottir, 2013, p. 2)

Skinner (1957) writes that a mand "works primarily for the benefit of the speaker; why should the listener perform the necessary mediation of reinforcement?" (p. 36). He goes on to argue for the necessity of understanding the whole speech episode; context is all because form alone does not make a verbal response a mand. Anand et al. (2004) have observed, "When newcomers are first exposed to ongoing unethical practices, they often experience significant dissonance and apprehension" (pp. 44-45). Bem (1967) states this condition succinctly:

if a person holds two cognitions that are inconsistent with one another, he will experience the pressure of an aversive emotional state called cognitive dissonance, a pressure he will seek to remove, among other ways by altering one of the dissonant cognitions. (p. 183)

Anand et al. (2004) see "rationalization" through metaphors as one of the measures to restore equilibrium. However, Palmer (1991) contends that rationalization and cognitive equilibrium are mental states and therefore not observable. It is difficult to ascertain if mental states have changed. In our view, examining the functional relation of verbal behavior and its environment is a more fruitful scientific undertaking.

In all relational exchanges between individuals, we can examine the use of metaphors from a two-factor perspective (Mowrer, 1956). Factor 1 is the positive reinforcement that the bribed officer may get or the prompt responsiveness the client may receive from the officer following the use of metaphors. Factor 2 comes into effect when a metaphor functions as a means of avoidance because the actors want to reduce the risk of accusation and punishment for corruption. Behavior analysts refer to doing something to prevent exposure to a fear-provoking stimulus as avoidance behavior (Azrin \& Holz, 1966). When the avoidance behavior reduces the fear, we say it reinforces behavior negatively by reducing or removing aversive stimulation. Both positive and negative reinforcement increase the probability of occurrence and maintenance of behavior in the future.

Analyzing the use of metaphors in corrupt behavior involves dealing with negative and positive reinforcement for the same behavior and interaction and this represents a challenge not only in analyzing the individual behavior but also in analyzing the interaction. It may be easier to change the functional relation between using a metaphor and the bribe, than stopping the avoidance behavior maintained by negative reinforcement. In the first case, one might be in 


\section{VERBAL OPERANTS OF CORRUPTION}

contact with the real reinforcing contingencies. In the latter, an avoidance of contact with consequences such as social stigma and punishments, which are intended to deter corruption may instead maintain corrupt behavior. Studies carried out in experimental and applied settings have demonstrated that avoidance behavior is extremely resistant to extinction (Sidman, 1960; Wilson \& Herrnstein, 1986).

\section{Corruption: Our Delineation}

There are several approaches to defining corruption. For the purposes of this article, we define corruption as:

a deviant behavior, which manifests itself in an abuse of a function in politics, society, or economy in favor of another person or institution. This abuse of function occurs on one's own or the other's initiative in order to achieve an advantage for oneself or a third party. (Rabl, 2008, p. 25)

Bribery manifests itself behaviorally in different forms. For instance, it could be when clients make payments for licit services to speed the work of a bureaucrat or when clients make payments for illicit services because the bureaucrat accords clients privileges that clients are not entitled to. Another form could be when value changes hands to prevent the bureaucrat from taking a decision that will harm the interest of clients (ControlRisks, 2014; Klitgaard, 1988). Excessive red tape; ritualized procedures, and arrogant and unresponsive bureaucrats are all possible causal antecedents creating opportunities for bribery (Dwivedi, 1990; Swamy, Azfar, \& Lee, 2001). We probe bribing behavior with the following questions: What common terms do people in Ghana use when demanding or offering bribes? Why is the of use metaphoric language preferred? What are the implications of the use of corruption language for combating corruption? We will proceed with a brief account of corruption in Ghana in the ensuing paragraphs.

\section{Corruption - Its Nature and Scope in Ghana}

Ghana has experienced continuous growth in consolidating its democracy, since returning to democratic rule in 1992 (Gyimah-Boadi, 2004). Most political and socio-economic commentators refer to Ghana as a success story among democracies in Africa (ISSER, 2011). However, corruption has been one of the major challenges confronting Ghana (Anin, 1975; Ayee, 2000; CDD, 2000; Ghana, 2011; LeVine, 1975; TI, 2013). The nature and scope of corruption in Ghana range from grand to petty corruption. The proceedings of the Commission on Judgment Debt, by Justice Apau, uncovered grand corruption cases of financial malfeasance and rot involving huge sums of money (Anas, 2014; ExposeGhana.com, 2013). According to Justice Apau, "Ghana's Public Treasury is a victim of 'mass rape and defilement' on a regular basis by the very people appointed to protect it" (Ghanaweb.com, 2013).

Studies have shown that some users of public service in Ghana have to make informal payments to obtain licenses, permits and other forms of authorization (Afrobarometer, 2012; CDD, 2000). An informal payment is an item in cash or kind that public officers demand from clients or clients offer public officers to perform their official duties even though no regulation mandates payment (Lewis, 2000; Rose-Ackerman, 1999; Vian et al., 2004). Basu (2011), labels this form of bribe as harassment bribe. $92 \%$ of the respondents in a survey conducted by Afrobarometer (2012) believed that officers were involved in corruption in Ghana. Ghana scored 48 points in 2014 and 46 points in 2013, on a scale of 1 to 100, where 1 denotes 'extremely 
corrupt' and 100 denotes 'not corrupt or least corrupt.' Transparency International (TI) ranked Ghana the $61^{\text {st }}$ most corrupt country in the world in 2014 (TI, 2014). Ghana's position has oscillated between $50^{\text {th }}$ and $70^{\text {th }}$ on the Corruption Perception Index (CPI) ranking since TI started its corruption measurement in 1998.

The rest of the article is structured as follows: In the first section, we provide a brief description of the research design and the collection of the data. The second section presents the data. We discuss the findings in section three. The last section of the article explores how contingencies can be arranged to stem the use of disguised mands in corruption behavior, and some suggestions for future research.

\section{Method}

It is a challenge for researchers to observe directly the phenomenon of corrupt behavior in vivo (Goldstein \& Pennypacker, 1998; Graaf, 2007; Treisman, 2000). Consequently, the dependent variable in most corruption studies tends not to be the observed behavior engaged in but rather the reports of the behavior. Researchers can use qualitative and quantitative methods in gathering data on corruption (Cavill \& Sohail, 2007).

\section{Data Collection}

We employed questionnaires to collect data on the personal experiences, views and experiences of friends and relatives on unofficial payments, from January to March in 2013. The questionnaires were given in English. We recruited respondents randomly from offices, markets, households, schools, universities, and voluntary organizations in Accra-Tema Metropolis, in Ghana. The introduction section of the questionnaire explained the objectives of the research. The respondents signed a consent form (informed consent), before the completion of the questionnaires. The researchers administered 259 questionnaires. We distributed 415 for selfadministration, and 259 were returned. The total number of completed questionnaires was 518 . The response rate was thus 100 per cent for the questionnaires administered by the researchers and $62.4 \%$ for the questionnaires distributed for self-administration. We offered two Keep-fit Clubs and three primary schools (which received questionnaires for onward distribution) three footballs for every ten duly completed questionnaires. We received $112(21.6 \%)$ completed questionnaires under this arrangement.

We asked the respondents to answer questions on the use of metaphoric language in soliciting or offering informal payments. Some of the questions were open-ended. In some questions, respondents could choose from among the alternatives we provided. We asked the following: Have you or anyone you know made informal payments to public officers for services provided? Do you think that people use metaphoric language rather than expressive language to solicit or offer informal payment and why the preference? We asked the respondents to give examples of such metaphors or language used by public officers and clients. We also asked a question on whether the language or metaphors are service or sector specific. Finally, we sought their views on the use of corruption language and anti-corruption work.

\section{Corruption Language - What Qualifies As a Metaphor?}

We collected over 1000 expressions/single words associated with bribing. However, before the categorization of the metaphors, we performed metaphor identification. We used the 


\section{VERBAL OPERANTS OF CORRUPTION}

identification process known as the Metaphor Identification Process (MIP), designed by the Pragglejaz Group (Wittink, 2011). The procedure has four stages: (a) the establishment of the general meaning of a text, (b) the determination of the lexical units of the text or discourse, (c) the establishment of the meaning in the context and lastly (d) the selection of the lexical unit as metaphorical, granting that it applies to an entity, relation or attribute in the situation.

\section{Presentation of Data}

We have organized the presentation on the strength of the questions we posed and later in the discussion section; we present them along with the research questions. We will begin this section with a brief presentation of the socio-demographic features of our respondents.

\section{Socio-Demographic Features of Respondents}

Data revealed that $93.4 \%$ of our respondents $(\mathrm{N}=518)$ lived in an urban area, and $5.4 \%$ lived in a rural area, while $1.2 \%$ did not answer this question. The vast majority of our respondents were from the Accra-Tema Metropolis. $63(12.2 \%)$ of the respondents $(\mathrm{N}=518)$ had a postgraduate degree, whereas $203(39.3 \%)$ had a degree. $101(19.6 \%)$ had a higher national diploma while $93(18 \%)$ had a secondary education. Finally, only $38(7.9 \%)$ had basic education, and $18(3.5 \%)$ of the respondents refused to answer this question. Evidently, our sample includes some highly educated professionals and civil servants and thus is not representative of the Ghanaian population as a whole, because our respondents have more formal education than the average Ghanaian. Consequently, this survey gives a fair picture of corruption perception among the educated middle class in the Accra-Tema Metropolis. We will proceed with the experience of our respondents on corruption in Ghana.

\section{Experience and Knowledge of Corruption}

We asked our respondents to indicate if they have or know people who have made informal payments before. Table 1 shows the distribution of their answers.

Table 1. Experience and knowledge of corruption behavior

\begin{tabular}{lll}
\hline & Frequency & $\%$ \\
\hline Not answered & 10 & 1,9 \\
Yes & 446 & 86,1 \\
No & 62 & 12,0 \\
Total & 518 & 100,0 \\
\hline
\end{tabular}


Table 2. Preference for metaphoric language

\begin{tabular}{lcc}
\hline & Frequency & \% \\
\hline Not answered & 41 & 7,9 \\
Yes & 414 & 79,9 \\
No & 46 & 8,9 \\
Do not know & 17 & 3,3 \\
Total & 518 & 100,0 \\
\hline
\end{tabular}

Data on this question show that $1.9 \%$ did not answer the question; while $86.1 \%$ of the respondents answered that they have, or know someone who has, made informal payment to an officer. Only $12 \%$ answered in the negative, and this is consistent with earlier studies of the existence of corruption in Ghana (Afrobarometer, 2012; CDD, 2000; GII, 2011; Hasty, 2005).

\section{Metaphor as Preferred Language}

We asked respondents to indicate if they thought people preferred to use corruption language rather than expressive language (straightforward language) when asking for or offering bribes. Table 2 shows the distribution of their responses.

As many as $79.9 \%$ of the respondents indicated that metaphor is preferable when soliciting or offering bribes and this confirms the observations made by other researchers (Adjei, 2009; Hasty, 2005; Polzenhagen \& Wolf, 2007) that metaphors are prevalent in the corruption discourse in Africa.

\section{Respondents Providing Examples of Corruption Language}

As shown in Table 3, majority of the respondents gave examples of corruption language that officers and clients use when soliciting or giving bribes. Ninety-five percent of the respondents provided examples of corruption phrases or words officials would use, whereas $81 \%$ provided examples that clients would use.

\section{Corruption Language - Categories}

Table 4 shows the categories and examples of expressions of corruption that our respondents associate with bribery behavior. Our respondents gave single words, phrases and sentences of corruption expressions. We created six categories from the examples collected. In Table 4 we show how many times the utterance occurs in the data, together with information on whom the respondents indicated would use it (public officer or client). 
VERBAL OPERANTS OF CORRUPTION

Table 3. Respondents providing examples of corruption language

\begin{tabular}{lll}
\hline & $\begin{array}{l}\text { Corruption } \\
\text { language used by } \\
\text { Officers }\end{array}$ & $\begin{array}{l}\text { Corruption } \\
\text { language used by } \\
\text { Clients }\end{array}$ \\
\hline $\begin{array}{l}\text { Number of respondents that provided } \\
\text { answers }\end{array}$ & $496(95.75 \%)$ & $420(81.10 \%)$ \\
$\begin{array}{l}\text { Number of respondents who did not } \\
\text { answer provide answers or provided } \\
\text { incomplete answers }\end{array}$ & $22(04.25 \%)$ & $98(18.90 \%)$ \\
\begin{tabular}{l} 
Total \\
\hline
\end{tabular} & 518 & 518 \\
\hline
\end{tabular}

Table 4. Corruption expressions - categories and examples

\begin{tabular}{|c|c|c|c|}
\hline \multirow{2}{*}{ Category 1 -Generic Corruption Language } & \multicolumn{3}{|c|}{ Number of Occurrences } \\
\hline & Total & Public Officers & Clients \\
\hline $\begin{array}{l}\text { Motivation (49), facilitation/facilitate (6), catalyst } \\
\text { (14), incentive ( } 7)\end{array}$ & 76 & 21 & 55 \\
\hline $\begin{array}{l}\text { Something related phrases/sentences-do } \\
\text { something, something for the boys, something the } \\
\text { children, something small, you need to do } \\
\text { something, something small for petrol, something } \\
\text { for the road, let something flow etc. }\end{array}$ & 340 & 184 & 156 \\
\hline $\begin{array}{l}\text { Hand related-hand go hand come, handshake, } \\
\text { you have POP-hands, stretch hand, oil hands }\end{array}$ & 57 & 34 & 23 \\
\hline It is our cocoa season (6); it is my Cocoa Tree (1) & 7 & 5 & 2 \\
\hline $\begin{array}{l}\text { Everybody benefits from his job, everybody chops } \\
\text { at his workplace }\end{array}$ & 44 & 44 & 0 \\
\hline Grease palm & 21 & 13 & 8 \\
\hline Envelope, enveloping & 80 & 43 & 37 \\
\hline $\begin{array}{l}\text { The weather is not good, weather no good, } \\
\text { weather is dry }\end{array}$ & 28 & 28 & 0 \\
\hline Weight-related-put weight on it, put weight on & 106 & 105 & 1 \\
\hline
\end{tabular}


paper, weight

Wash my feet

Bail yourself

Water the ground

For the road

Sow some seed

Process you for court

The ball is in your court

Pocket related - pocket is not good/pocket is dry,

for your pocket

What did you bring?

Chop money, we go chop

Advise yourself

expect me to eat your thank you? Thanking me with empty hands

I will sort you out

Put tag on it

How did you come?

The weekend is here

Scratch my back

12

5

3

Welfare

6

5 Show appreciation - I will
show your appreciation

\section{Category 2-Water food drink}

\section{Number of Occurrences}

\section{Total Public Officers Clients}

\footnotetext{
${ }^{2}$ Goro is the local name for kola nut, a caffeine-containing nut widely used in West Africa as a stimulant.
} 
Beverage related - beer money (9), water/pure

(1)

\begin{tabular}{lccc} 
Lunch & 65 & 6 & 59 \\
Kooko $^{4}$ & 23 & 14 & 9 \\
\hline Category 3-Tradition and Customs & \multicolumn{2}{c}{ Number of Occurrences } \\
\cline { 2 - 4 } & Total & Public Officers & Clients \\
\hline Tradition & 24 & 18 & 6 \\
Protocol & 24 & 15 & 9 \\
Rite & 7 & 4 & 3 \\
Libation & 92 & 47 & 45 \\
Custom & 29 & 21 & 8 \\
Do the proper thing & 5 & 5 & 0 \\
\hline
\end{tabular}

Category 4-Transportation and Communication
Number of Occurrences

Total Public Officers Clients

\begin{tabular}{|c|c|c|c|}
\hline Fuel & 18 & 1 & 17 \\
\hline Transportation/petrol for car & 36 & 10 & 26 \\
\hline Credit for telephone & 18 & 5 & 13 \\
\hline \multirow{2}{*}{$\begin{array}{l}\text { Category } 5 \text {-Jargons and local language } \\
\text { phrases }\end{array}$} & \multicolumn{3}{|c|}{ Number of Occurrences } \\
\hline & Total & Public Officers & Clients \\
\hline Soli $^{5}$ & 19 & 19 & 0 \\
\hline \multicolumn{4}{|l|}{ Gyewu $^{6}$} \\
\hline \multicolumn{4}{|l|}{ Wawiea fa me Anas mamie } \\
\hline Aha die saa nayeye noo! ${ }^{7}$ & & & \\
\hline
\end{tabular}

${ }^{3}$ Sika means money or gold

${ }^{4}$ A maize porridge

${ }^{5}$ An abbreviation of solidarity

${ }^{6}$ An Akan phrase meaning "my father is dead"

${ }^{7}$ This is the way we do it here! 


\begin{tabular}{lccc}
\hline \multirow{2}{*}{ Category 6-Proverb or adage related phrases } & \multicolumn{3}{c}{ Number of Occurrences } \\
\cline { 2 - 4 } & Total & Public Officers & Clients \\
\hline Nobody shows a child who God is & 1 & 1 & 0 \\
We use bait to catch a fish & 1 & 1 & 0 \\
\hline
\end{tabular}

The examples show that some of the expressions are peculiar to public officers or clients. In category one, data revealed that public officers may use expressions such as "it is our cocoa season," "it is my cocoa tree," "everybody benefits from his job" to solicit bribes. Clients would use expressions like "I will sort you out," "I will show my appreciation," and "I will envelop you" to offer a bribe. However, the person soliciting may use phrases like "something small" or "put weight on it" to construct sentences. In category two, words and phrases like "kola" or "goro" (cola nut), "beer money," "water," "ice water," "coke," "coffee," "energy drink," "fanta sika", "lunch" and "kooko"9 are prevalent. Both public officers and clients use drinks and edibles to solicit or offer bribes. We labeled category three "tradition and custom." Here, the person asking for or offering a bribe may use single words like, "tradition," "protocol," "rites," "libation" and "custom," or employ the following expressions; "you know the custom," "you have to pour libation," "you know the tradition," "I will perform the tradition" and "I know the protocol." We created a fourth category for transport and communication-related words and phrases such as "fuel money," "transport," "T\&T," "petrol for car" and "credit for mobile telephone." Category 5 consisted of jargons and local language phrases, like "soli" "gyewu" " "se wawiea dia fa me Anas mamie." 12 The data had only two examples this category, however, further research may show that there may be more such expressions because the use of proverbs in communication is common in African societies (Mbiti, 2002). African proverbs are often situational and the meaning to a large extent depends on the context in which they are expressed (Dzobo, 1973; Yankah, 2012).

\section{Preference for Metaphoric Language}

Respondents had to select three options from six reasons we provided, to indicate why they would prefer to use euphemisms rather than expressive language when soliciting or offering bribes. Table 5 shows the distribution of the choices respondents made in respect of each reason.

Data revealed that most of the respondents selected the following in a descending order D, $\mathrm{B}, \mathrm{A}, \mathrm{C}, \mathrm{E}$ and F. D was the most selected, while F was the least.

\footnotetext{
${ }^{8}$ Money

${ }^{9}$ Maize porridge often taken as breakfast

${ }^{10}$ An abbreviation of solidarity

${ }^{11}$ Father is dead or I am bereaved

${ }^{12}$ Anas is a Ghanaian investigative journalist who has uncovered many human rights abuses and corruption cases. Ironically, some public officers use his name to solicit bribe.
} 
Table 5. Why corruption language is preferred.

\begin{tabular}{|c|c|c|c|c|c|}
\hline \multirow[t]{2}{*}{ Reasons } & \multicolumn{2}{|c|}{$\begin{array}{c}\text { Number of } \\
\text { respondents who } \\
\text { selected this reason }\end{array}$} & \multicolumn{2}{|c|}{$\begin{array}{c}\text { Number of } \\
\text { respondents who did } \\
\text { not select this reason }\end{array}$} & \multirow[b]{2}{*}{ Total } \\
\hline & Frequency & $\%$ & Frequency & $\%$ & \\
\hline $\begin{array}{l}\text { A. Expression of caution so as } \\
\text { not to offend the service } \\
\text { provider or public officer }\end{array}$ & 300 & 57.9 & 218 & 42.1 & $\begin{array}{c}518 \\
(100)\end{array}$ \\
\hline $\begin{array}{l}\text { B. It allows the receiver of the } \\
\text { message to determine its } \\
\text { content }\end{array}$ & 351 & 67.8 & 167 & 32.2 & $\begin{array}{l}518 \\
(100)\end{array}$ \\
\hline $\begin{array}{l}\text { C. Do not want to be offensive, } \\
\text { because intimating that an } \\
\text { officer is corrupt is aversive }\end{array}$ & 296 & 57.1 & 222 & 42.9 & $\begin{array}{l}518 \\
(100)\end{array}$ \\
\hline $\begin{array}{l}\text { D. Do not want to embarrass the } \\
\text { person }\end{array}$ & 372 & 71.8 & 146 & 28.2 & $\begin{array}{l}518 \\
(100)\end{array}$ \\
\hline $\begin{array}{l}\text { E. It makes the offer more } \\
\text { acceptable }\end{array}$ & 233 & 45.0 & 285 & 55.0 & $\begin{array}{c}518 \\
(100)\end{array}$ \\
\hline $\begin{array}{l}\text { F. It hides the illegal dimension } \\
\text { of the act }\end{array}$ & 209 & 40.3 & 309 & 59.7 & $\begin{array}{l}518 \\
(100)\end{array}$ \\
\hline
\end{tabular}

\section{Specificity of Metaphors to Sectors}

Do specific sectors in the public administration have their distinct language? We asked respondents who answered in the affirmative to provide examples. Almost $64 \%$ indicated that metaphors were not sector specific (Table 6).

The total number of respondents who gave examples of sector-specific corruption language reflects this view. Only 70 persons constituting $13.5 \%$ of the 518 respondents gave examples of metaphors deemed sector-specific. "I will process you," "bring your particulars," and "your documents" were some of the expressions the police might use, especially in the case of trafficrelated offenses. The respondents linked the word "soli" to journalists (Polzenhagen \& Wolf, 2007. The word "gyewu" was associated with officers of the Ghana Revenue Authority, while "se wawiea dia fa me Anas mamie" was linked to Custom and Immigration Services.

\section{Corruption Language Perpetuates Corruption}

In all, 294 respondents expressed their views on why corruption language might perpetuate corruption. We identified three major views: it does not offend or embarrass; its polysemous nature makes the gathering of evidence challenging, and it legitimizes corrupt behavior and makes it acceptable. Table 7 shows some of the examples of the views expressed by respondents. These views seem to align with the alternatives chosen by respondents on why people prefer the usage of figurative language. We will address this alignment in our discussion. 
Table 6. The specificity of metaphors to sectors

\begin{tabular}{lcc}
\hline & Frequency & $\%$ \\
\hline Not answered & 48 & 9,3 \\
Yes & 139 & 26,8 \\
No & 331 & 63,9 \\
Total & 518 & 100,0 \\
\hline
\end{tabular}

\section{Discussion}

While the functional analysis of behavior traditionally requires experimental control to produce robust knowledge, our daily lives are mainly based on the knowledge derived from interpretation (Palmer, 1991). There are contingencies of reinforcements operating on exchanges of bribes for favors, for both parties to the transaction. Applying behavioral principles to analyze everyday behavior, in everyday settings is interpretation in practice. Corruption phenomenon occurs in circumstances that are difficult to examine in situ, because it is a criminal activity and persons engaged in it try to hide and protect it by secrecy (Luo, 2004 ). Baer, Wolf, and Risley (1968) argue that behavior analysts should be concerned with a behavior not because that behavior is easy to study, but because that behavior is important (p. 92). They acknowledged that socially important behavior may not be amenable to experimental studies in most cases, hence the imperative function of interpretation as an analytical tool. We have not based this article on experimental data, but its analysis rests on experimentally derived principles. The study interprets corrupt behavior from the initial contact to the eventual pay-off, in terms of reinforcement contingencies, using data provided by 518 completed questionnaires.

\section{Corruption Language in Corruption Behavior}

What common terms do people use when they offer or accept a bribe in Ghana? Our respondents associated a plethora of figurative expressions with corruption, and some of the expressions depicted in this article show how imaginative people could be. For example, "A page is missing from your passport" could be an Immigration Officer saying there should be a currency note in the passport. Other examples in this group are expressions like "put weight on it," "the ground is dry," and "water the ground." Another interesting revelation is the use of the word "something". It featured in most lexical items and expressions, appearing 340 times in the examples given. "Something" is a pronoun, which expresses that a thing is uncertain or unspecified. By employing the pronoun, one eschews being lexically exact. The works of Adjei (2009); Henig (2013), and Polzenhagen and Wolf (2007) on corruption in Africa underscored this observation. The novelist Adichie (2013), accentuated the behavior of not being direct when asking for money with the following narrative: 
But you should do something for him, no matter how small, otherwise he will not leave you alone, she said. 'Do something for him' meant give him money and Obinze, all of a sudden, hated that tendency of Igbo people to resort to euphemism whenever they spoke of money, to indirect references, to gesturing instead of pointing. Find something for this person. Do something for that person. It riled him. It seemed cowardly, especially for a people who otherwise were blisteringly direct. (p. 465)

Data also showed that the metaphorical conceptualization of corruption is quite varied, comprising both tangible and intangible items. "Show your love," "chop money," "solidarity,"

Table 7. Views on why metaphors perpetuate corruption language-examples

\section{A. It does not offend or embarrass}

\begin{tabular}{|c|c|c|c|c|}
\hline $\begin{array}{l}\text { It makes it less } \\
\text { aversive and less } \\
\text { embarrassing }\end{array}$ & $\begin{array}{l}\text { It makes asking } \\
\text { and giving easier } \\
\text { because you can } \\
\text { pack something } \\
\text { that is difficult or } \\
\text { unpleasant to talk } \\
\text { about directly }\end{array}$ & $\begin{array}{l}\text { It is easier to } \\
\text { communicate } \\
\text { and also makes it } \\
\text { appear cool }\end{array}$ & $\begin{array}{l}\text { It is easier to } \\
\text { solicit or give } \\
\text { bribe because } \\
\text { people say it in a } \\
\text { jovial and not a } \\
\text { provoking } \\
\text { manner }\end{array}$ & $\begin{array}{l}\text { It is morally less } \\
\text { offensive; you do } \\
\text { not feel any guilt }\end{array}$ \\
\hline
\end{tabular}

\section{B: Its polysemous nature makes the gathering of evidence challenging}

\begin{tabular}{|c|c|c|c|c|}
\hline $\begin{array}{l}\text { Asking is easier } \\
\text { when it is done } \\
\text { indirectly; you } \\
\text { can always say } \\
\text { that was not what } \\
\text { I meant if the } \\
\text { person addressed } \\
\text { takes offense }\end{array}$ & $\begin{array}{l}\text { It makes the } \\
\text { public officer } \\
\text { more } \\
\text { comfortable in } \\
\text { accepting the } \\
\text { offer. They are } \\
\text { not threatened } \\
\text { because it hides } \\
\text { the illegal } \\
\text { intentions }\end{array}$ & $\begin{array}{l}\text { It makes the } \\
\text { system hard to } \\
\text { penetrate }\end{array}$ & $\begin{array}{l}\text { It is difficult to } \\
\text { prove in any } \\
\text { court of law } \\
\text { should the use of } \\
\text { metaphors be } \\
\text { tendered as } \\
\text { evidence for } \\
\text { prosecution }\end{array}$ & $\begin{array}{l}\text { You can always, } \\
\text { as a giver or a } \\
\text { receiver say that } \\
\text { was not what you } \\
\text { meant if caught }\end{array}$ \\
\hline
\end{tabular}

\section{C: It legitimizes corruption behavior and makes it acceptable}

\begin{tabular}{|c|c|c|c|c|}
\hline $\begin{array}{l}\text { Because as soon } \\
\text { as the receiver } \\
\text { agrees or } \\
\text { cooperates } \\
\text { positive results } \\
\text { are seen } \\
\text { immediately }\end{array}$ & $\begin{array}{l}\text { People see it as } \\
\text { normal and do } \\
\text { not realize they } \\
\text { are doing } \\
\text { something wrong } \\
\text { because people } \\
\text { use it both public } \\
\text { and private } \\
\text { domains }\end{array}$ & $\begin{array}{l}\text { Because it } \\
\text { disguises } \\
\text { corruption } \\
\text { process as an act } \\
\text { of friendliness } \\
\text { rather than illegal }\end{array}$ & $\begin{array}{l}\text { It makes it look } \\
\text { like any friendly } \\
\text { transaction } \\
\text { because informal } \\
\text { tone makes the } \\
\text { act of soliciting } \\
\text { or giving less } \\
\text { aversive }\end{array}$ & $\begin{array}{l}\text { Because as soon } \\
\text { as the receiver } \\
\text { agrees or } \\
\text { cooperates } \\
\text { positive results } \\
\text { are seen } \\
\text { immediately }\end{array}$ \\
\hline
\end{tabular}


and "something small" are the examples of intangibles, while "kola," "goro" (cola nut), "beer money" and "ice water" are examples of tangible items. Cola nut is a traditional edible item in West Africa. Both the giver and taker may use COLA $^{13}$ when soliciting or offering bribes. The expression "Everybody benefits from his work" or "Everybody chops at his workplace" epitomizes the endemic nature of corrupt behavior in Ghana. A former Acting Director of the Serious Fraud Office considered the above notion so compromising and damaging to public service ethics that he called for the:

Removal of the notion: 'Chopping' at one's workplace. We appear to have accepted as a norm that one has to 'chop' at one's workplace. The meaning attached to this saying is that apart from your salary and fringe benefits, it is normal for you to engage in practices that can bring you some financial or material gain; therefore, it is normal for a Custom officer, for instance, to receive gifts from an importer. We ought to say no to this notion in the first place (Hasty, 2005, p. 276).

On January 29, Graphic.com (2015), carried a news item on a doctor who defrauded the National Health Insurance Authority of ca. 126,255 USD. He added a cover note to the bribe he gave to the controller with the following words: "Dear Doc, this is something small for your hard work. It is not a bribe. Take it and relax. In Ghana, everybody 'chops' from his work side. ${ }^{14}$ From your friend, Doctor Ametewee". The expression everybody chops at one's workplace is consistent with the metaphor of the ledger. In the metaphor of the ledger actors justify their deviant behavior by claiming, they have the "right" to behave as they do, because of their contribution (effort and time) to the success of the organization (Anand et al., 2004, p. 16). The commonness of lexical items and the expressions that the research exposes indicate a strong presence of a corruption culture in Ghana.

\section{Positive and Aversive Contingencies}

Why are the of use metaphoric language preferred to direct (plain) language? As noted above, despite the existence and the endemic nature of corruption, there is no open cultural approval of the corruption behavior. All jurisdictions condemn corruption as shameful and unethical, and there are laws against it (Noonan, 1984), this may explain the proclivity to use figurative language (De Sardan, 1999). Legal measures to contain bribery use either symmetric liability (the bribe-giver and the recipient are culpable) or asymmetric liability (only the recipient is culpable). Symmetric liability is one of the pivots of Ghana's Anti-Corruption Laws. Persons convicted of the offence under the code are liable upon conviction to a fine of not less than 500 Cedis $^{15}$ or imprisonment not exceeding ten years or both. There may be strong positive reinforcement contingencies for both the officer and the client to engage in corruption. Since Criminal Offences Act (1960) criminalizes bribery, both the officer and the client might have strong incentives to avoid mutually the accusation of corruption by using euphemisms to neutralize the legal hazards and social embarrassment (Mowrer, 1956). Avoiding the sanctions specified by the law is a desirable outcome for both parties (Azrin \& Holz, 1966).

\footnotetext{
${ }^{13}$ COLA is an acronym for Cost of Living Allowance. However, it may refer to coca cola or cola nut.

${ }^{14}$ Work side is a Ghanaian Pidgin English expression for workplace.

${ }^{15}$ The estimated exchange rate was 2.018 Cedis to a US dollar in 2013 and 1.1 in 2008 (CIA, 2014).
} 


\section{VERBAL OPERANTS OF CORRUPTION}

If a client interprets an expression emitted by an officer, for instance, "the weather is dry" on its face value, and no bribe is forthcoming, the officer would not have said anything incriminating. If the client offers to "perform the tradition," his choice of words may be innocuous and similarly exempt him or her from being charged with corruption. On the other hand, if both parties understand the words or phrases as metaphoric expressions for soliciting or offering a bribe, the corrupt exchange materializes. Both parties have avoided discussing in plain language a shameful and illegal activity (Ashforth \& Anand, 2003; Hasty, 2005). Therefore, corruption language maintains the positive reinforcement contingencies of getting an application approved or delivery of service for the client, while protecting both the officer who collects bribes and his client from being charged with corruption.

Almost $79 \%$ of the respondents construed metaphors as hints to engage in corruption, because the context of the speaker's utterances facilitates this comprehension of the verbal behavior (Skinner, 1957). Euphemistic language has another function. It helps the user to tackle insecurity. An official uncertain of the inclinations of a client and vice versa may use a metaphoric language to solicit or offer a bribe. Metaphors are polysemous, and they give the officer and client the chance to exhibit avoidance behavior, should one encounter a "noncorruptible officer" or a non-corruptible client. 209 respondents, constituting $40.3 \%$ of the total number, chose the alternative "it hides the illegal dimension of the act" as a reason for why figurative expressions are preferred. To traverse the illegal terrain of corruption without emitting aversive stimuli, a verbal community coins its language. It is not surprising that 300 of the respondents $(57.9 \%)$ gave the reason "expression of caution so as not to offend the service provider or the public officer," whiles $372(71.8 \%)$ gave the reason "don't want to embarrass the person" for preferring figurative language.

\section{Metaphors and Anti-Corruption}

Existing literature (Ashforth \& Anand, 2003; Hasty, 2005; Polzenhagen \& Wolf, 2007) and our data, have documented the prevalence of figurative language associated with corruption behavior in Ghana. We asked respondents to express their views on what implications of the use of corruption metaphor (disguised mand) may affect anti-corruption work. We grouped the various views provided by 294 respondents (56.6\%) under the following headings: "It does not offend or embarrass," "Its polysemous nature makes the gathering of evidence challenging," and "It legitimizes corrupt behavior and makes it acceptable." We have provided examples of the views in Table 7. According to our respondents, the use of corruption language in transacting administrative business normalizes corruption. People deem corruption legitimate or that it is normal to "chop" at one's workplace in addition to the salary and fringe benefits provided them (Adjei, 2009; Hasty, 2005). Hasty (2005, p. 276), observed that it is normal for public officers to engage in "practices that can bring financial or material gain."

\section{Corruption Language is Not Offensive}

Corruption behavior is illegal and morally frowned upon by society. To be associated with corruption or to imply that someone is corrupt, may be offensive. If you suggest that someone is corrupt, you emit an aversive stimulus, and it could attract punishment. New organizational participants exposed to "unethical practices often experience significant dissonance and apprehension" and organizational actors would use euphemisms to socialize those who 
experience "cognitive dissonance" into accepting the culture of corruption (Anand et al., 2004, pp. 45, 55).

\section{Corruption Language—Evidence Gathering}

The polysemous nature of the metaphors leaves open the possibility for both the one soliciting and the one offering a bribe to switch between the language of corruption, and the common meaning in the larger verbal community. For example, asking for candy may well be an invitation to bribery; on the other hand, it is no criminal offense to ask someone for candy. It may be difficult to collect evidence and charge persons by the anti-corruption law.

The discussion in this section shows that corruption language mediates the reinforcement contingencies of the interactions between the officer and the client. The antecedents and the consequences that characterize the interaction will influence behavior (Baum, 2005; Catania, 2013). For example, officials exercising public authority have a monopoly in granting permits, licenses, and approvals. Public officers could resort to non-responsive actions such as delays in processing applications if clients ignore metaphors beckoning them to give bribe. One of our respondents commented, "It would cost you more money in the long run, if you decline to pay the bribe, so you continue to pay bribe to get things done quickly, time is money you know." According to (Abbink, Dasgupta, Gangadharan, \& Jain, 2014):

The typical bribe-giver, who is an ordinary client, is in a dilemma when faced with a bribe demands from a public official. Refusal to pay implies considerable inconvenience or loss due to a certain delay in receiving the service, while succumbing to bribe giving makes her legally culpable should the transaction be discovered. (p. 18)

Corruption language is conceivable, because verbal behavior is contextually framed. The situation of soliciting and offering bribes is secret and conspiratorial. The "opaque" language that enhances deniability for both conspirators accentuates the secret behavior. Since the corrupter and the corruptee are culpable, they are in essence engaged in a Prisoner's Dilemma (Axelrod, 1984). They know the contingencies well enough to engage in a behavior that yields maximum payoff because the alternative is punishment for both.

As previously noted, form alone does not make a verbal response a mand. The mand specifies its reinforcer, and the controlling antecedents are specific deprivation or aversive stimulation. Metaphors are ambiguous and permit deniability, embarrassment avoidance, and successful solicitation or offering of bribes. They are completely dependent on strong contextual control. There is mutual understanding between the public officer and the client that the innocuous utterance is in invitation to break the anti-corruption law.

The Transparency International Index measures the "perceived levels of public sector corruption" (TI, 2014). The index measures the degree of the pervasiveness of corruption in the different countries listed and gives, therefore, an indication of the likelihood to encounter corruption in the cultures. Corruption is a cultural phenomenon and combating it requires a better understanding of how cultural selection processes work and how they can be influenced. To sum up, corruption language perpetuates corruption behavior because it does not offend or embarrass, it 'legitimizes' corrupt behavior and makes it acceptable. Moreover, its polysemous nature makes the gathering of evidence a challenging exercise. Another element is that both the official and the client are under concurrent and strong contingencies of positive reinforcement and avoidance. The question then is how to arrange contingencies to change the unwanted behavior. 


\section{VERBAL OPERANTS OF CORRUPTION}

Under concurrent and strong contingencies of positive reinforcement and avoidance, the behavior is highly resistant to change (Catania, 2013). Azrin \& Holz (1966) and Johnston (1972) describe general principles for effective punishment. The principles are an immediate and continuous schedule of the application of punishing stimulus; no possibility to escape the punishing stimulus; maximum intensity right away; no reinforcement for the punished response, and access to alternative responses that can be amply reinforced. To use the above as guiding principles to arrange contingencies to counteract the use of corruption language would be difficult for several reasons. Firstly, the complicity to commit it is secretive. Secondly, the actors have no incentives to report corrupt behavior. If the officer and the client have a stake in keeping their "corrupt business" furtive, they will find a way to do so, consequently the principles enumerated by Azrin and Holz (1966) are not applicable. The strength of the positive reinforcement in corruption behavior (bribery), combined with the low probability of being caught, generate behavioral patterns that are very difficult to correct, thus making the contingencies influencing corrupt behavior practically impossible to alter by themselves. In our view, the contingencies that influence verbal behavior shape and maintain the social behavior in powerful ways. They are the tools of cultural selection. The widespread use of disguised mands associated with corruption in Ghana manifests the selection of a corruption culture.

\section{Summary and Concluding Remarks}

We have analyzed in this article disguised mands (corruption language) people use in soliciting or offering bribes in Ghana, from a behavior analytic perspective. Questionnaires were used to elicit data from 518 persons on the subject of inquiry. Our data revealed that the usage of metaphors and euphemisms (disguised mands) is prevalent in Ghana. We highlighted reasons why the usage of disguised mands is preferred when soliciting or offering bribe: It is used as an avoidance stratagem, to manage the uncertainty, and possibly to make a retreat. We can allege that the usage of disguised mands allows corrupt behaviors to pass "below the radar" for what is punishable by law because topographically the metaphorical expressions can be neutral phrases.

Using functional analysis, we examined the relational exchanges between the official and the client from a two-factor perspective. We found out that users of disguised mands concerning corruption behavior could come under concurrent contingencies of positive and negative reinforcements. The question then is how can we deal with the usage of disguised mand concerning corruption behavior?

Interventions designed to change behavior can have four basic directions, and they may be combined and nuanced for specific behavioral targets. Existing behavior may be increased; new behavior can be established; the stimulus control for existing repertoires can be changed, and the existing repertoires can be reduced or even eliminated. Elimination of a behavior can be attained through extinction, punishment or satiation. Basic research on non-humans and humans suggests that effective punishment is extremely difficult to implement. The target response must be punished immediately and every time it occurs, with maximum intensity. Reinforcers maintaining the punished response must be eliminated, and there must be alternative responses available (Azrin \& Holz, 1966; Johnston, 1972). In corruption behavior, extinction procedure would be extremely difficult to implement, since the act of corruption occurs covertly most of the time. Increasing and extending existing repertoires may not be efficacious in a culture 'completely soaked' in corruption and this leaves establishing new behavior and changing stimulus control of existing repertoires as plausible alternatives. 
Establishing new behavior and changing stimulus control of existing repertoires informed the constructional approach of the psychiatrist Israel Goldiamond. Goldiamond (2002) advocated for "the construction of repertoires (or their reinstatement or transfer to new situations) rather than the elimination of repertoires" (p. 121). We will use a cultural selection perspective, as our point of departure, to suggest measures to tackle the usage of disguised mands in corruption related behavior. Consequently, we see the use of disguised mands as a cultural practice of the verbal community that maintains corruption behavior. To change a culture including verbal behavior, a variation upon which selection can operate, is necessary. The use of metaphors in corruption behavior has detrimental consequences and implications for society. According to Biglan and Glenn (2013):

it is in the interest of any social system to identify macrobehaviors ${ }^{16}$ with beneficial or harmful effects and arrange contingencies of reinforcement that produce and sustain operant behavior contributing to the beneficial effects and avoiding the harmful one. (p. 256)

Corruption cultures are the cumulative outcome of individual decisions that are made without regard to the consequences for the collective and hence our focus should be on changing cultural practices. Behavioral research has shown that legislation (Seekins et al., 1988), signs and prompters (Williams, Thyer, Bailey, \& Harrison, 1989), and signed promise cards (Geller \& Lehman, 1991), have been effective in changing cultural practices.

Several measures may be adopted to change the cultural practice of using disguised mands related to corrupt behavior. Awareness creation on the negative externalities of corrupt behavior, made possible by the use of corrupt language to the public could be an anti-corruption measure. It is one thing saying, "Everybody chops from his workplace." We know this is a bad behavior. However, it may have a different impact if one is made aware of the millions of dollars stolen because of this seemingly innocuous euphemism.

Another measure could be posting visible proclamations like "Plain talk-honest service" in the offices of public servants. Informational materials on how to behave when one encounters corrupt officers or corrupt clients who use disguised mands is also another measure. Information on how to tackle (parry) disguised mands with anti-corruption language can be one way to dismantle the relationship between corruption metaphors and bribery. The above measures may create cognitive dissonance or disturbance for the party employing disguised mands for a corrupt act. Raising the awareness of disguised mands associated with corruption behavior by highlighting the topic in training programs for public officials and the curriculum for students and school pupils, could be another policy measure. All the above suggestions are workable, low-cost strategies with evidence of efficacy in other settings.

Finally, if we view corruption as a cultural phenomenon, we have to probe the contingencies governing the interactions between officials and clients, and the cultural contingencies that encourage and maintain the practice in a verbal community. Behavior analysis has the theoretical and experimental tools for this task. We, therefore, call for more studies that employ behavior analysis to explain and interpret corruption, which is undoubtedly one of the wicked problems confronting the world in the 21 st century.

\footnotetext{
${ }^{16}$ The aggregate measure of the behavior of many individuals.
} 


\section{VERBAL OPERANTS OF CORRUPTION}

\section{References}

Abbink, K., Dasgupta, U., Gangadharan, L., \& Jain, T. (2014). Letting the briber go free: an experiment on mitigating harassment bribes. Journal of Public Economics, 111, 17-28. doi: 10.1016/j.jpubeco.2013.12.012

Adichie, C. N. (2013). Americanah. London: Fourth Estate.

Adjei, M. (2009). Corruption and The Body Politic in Post-Colonial Ghana: A Re-reading of Amu Djoleto's Money Galore in the Era of 'Zero Tolerance for Corruption in Ghana. Legon Journal of the Humanities, 20, 89-103.

Afrobarometer. (2012). Round-5 2011/2012. Available. Retrieved from http://www.jdsurvey.net/afro/afrobarometer.jsp.

Anand, V., Ashforth, B. E., \& Joshi, M. (2004). Business as usual: The acceptance and perception of corruption in organizations. The Academy of Management Executive, 18(2), 39-55.

Anas, A. A. (2014). Soul Takers. An undercover investigative film. In T. EYE (Producer). Accra.

Anin, P. D. (1975). Final Report of the Commission of Enquiry into Bribery and Corruption. Accra: Ghana Publishing Corp (Print Division).

Ashforth, B. E., \& Anand, V. (2003). The normilization of corruption in organizations. Research in Organizational Behavior, 25, 1-52. doi: 10.1016/S0191-3085(03)25001-2.

Axelrod, R. (1984). The evolution of cooperation. New York: Basic Books.

Ayee, J. R. A. (2000). Ghana: the continuing search for cures in the fight against corruption. In K. R. Hope \& B. C. Chikulo (Eds.), Corruption and Development in Africa: Lessons from country case-studies. Basingstoke: Macmillan.

Azrin, N., \& Holz, W. K. (1966). Operant behavior. Areas of research and application In W. K. Honig (Ed.), Punishment (pp. 380-447). New York: Appleton-Century-Crofts.

Azrin, N. H., \& Holz, W. C. (1966). Punishment. In W. K. Honig (Ed.), Operant behavior. Areas of research and application (pp. 380 -447). New York: Appleton-Century-Crofts.

Baer, D. M., Wolf, M. M., \& Risley, T. R. (1968). Some current dimensions of applied behavior analysis. Journal of Applied Behavior Analysis, 1(1), 91-97. doi: 10.1901/jaba.1968.1-91.

Basu, K. (2011). Why, for a Class of Bribes, the Act of Giving a Bribe should be Treated as Legal. Retrieved from http://mpra.ub.uni-muenchen.de/50335/1/MPRA paper 50335.pdf.

Baum, W. M. (2000). Being concrete about culture and cultural evolution. In F. Tonneau \& N. Thompson (Eds.), Perspectives in Ethology (Vol. 13, pp. 181 - 210). New York: Springer.

Baum, W. M. (2005). Understanding behaviorism: behavior, culture and evolution. Oxford: Blackwell.

Bem, D. J. (1967). Self-perception: An alternative interpretaion of cognitive disonance phenomena. Psychological Review, 74(3), 183-200. doi: http://dx.doi.org/10.1037/h0024835.

Biglan, A., \& Glenn, S. S. (2013). Toward prosocial behavior and environments: Behavioral and cultural contingencies in a public health framework. In G. J. Madden, W. V. Dube, T. D. Hackenberg, G. P. Hanley, \& K. A. Lattal (Eds.), APA Handbook of Behavior Analysis (Vol. 2, pp. 255-275). Washington DC: DC: American Psychological Association.

Catania, C. A. (2013). Learning (5 ed.). Cornwall-on-Hudson, N.Y.

Cavill, S., \& Sohail, M. (2007). Accountability arrangements to combat corruption: A note on research methodology for combating corruption. Loughborough, UK: WEDC.

CDD. (2000). The Ghana Governance and Corruption Survey. Evidence from Households, Enterprise and Public Officials Accra: Centre for Democratic Development (CDD).

Chomsky, N. (1967). A Review of B. F. Skinner's Verbal Behavior. In L. A. Jakobovits \& M. S. Miron (Eds.), Readings in the Psychology of Language (pp. 142-143). Prentice: Hall.

Chomsky, N. (1986). Knowledge of language: Its nature, origin, and use. New York: Praeger.

ControlRisks. (2014, September 09). Anti-Bribery and Anti-Corruption Policy. Retrieved September 09, 2015 from http://www.controlrisks.com/en.

Criminal Offences Act of Ghana, 1960 (Act 29). (Amendment) Act, 2003 (Act 646).

Cuddon, J. A., \& Preston, C. E. (1998). A dictionary of literary terms and literary theory. Oxford: Blackwell.

Ding-an-sich. (n.d). www.oxforddictionaries.com. Ding-an-sich definition. Retrieved from http://www.oxforddictionaries.com/definition/english/Ding-an-sich.

De Sardan, J. P. O. (1999). A Moral Economy of Corruption in Africa? The Journal of Modern African Studies, 37(1), 25-52. doi: http://www.jstor.org/stable/161467.

Dwivedi, O. P. (1990). Administrative Theology: Dharma of Public Officials. I.J.PA., XXXVI (No. 3; JulySeptember). 
Dzobo, N. K. (1973). African Proverbs: The moral value of Ewe proverbs: University of Cape Coast, Department of Education.

Euphemism. (n.d.). www.oxforddictionaries.com. Euphemism definition. Retrieved from http://www.oxforddictionaries.com/definition/english/euphemism.

ExposeGhana.com. (2013, July 10). Ghana Judgement Debts Archives - exposeGhana.com. Retrieved from http://exposeghana.com/tag/ghana-judgement-debts/.

Geller, E. S., \& Lehman, G. R. (1991). The Buckle-up Promise Card: a versatile intervention for large-scale behavior change Journal of Applied Behavior Analysis, 24(1), 91-94. doi: 10.1901/jaba.1991.24-91.

Ghana. (2011). National Anti-Corruption Plan (NACAP). Accra. Retrieved from http://www.chrajghana.com/wpcontent/uploads/2012/08/nacap.pdf.

Ghanaweb.com. (2013, September 30). Nobody cares about what happens to public funds - Justice Appau. Retrieved from http://www.ghanaweb.com/GhanaHomePage/NewsArchive/Nobody-cares-about-whathappens-to-public-funds-Justice-Appau-287421.

GII. (2011). The "Voice of the People" Survey. A survey of corruption in Ghana. Act Now Against Corruption in Ghana. Retrieved from GII - Ghana Integrity Initiative. http://www.tighana.org/giipages/publication/Voice\%20of\%20the\%20people\%20Survey.pdf.

Goldiamond, I. (2002). Toward a constructional approach to social problems: ethical and constitutional issues raised by applied behavior analysis. Behavior and Social Issues, 11, 108 - 197.

Goldstein, M. K., \& Pennypacker, H. S. (1998). From Candidate to Criminal: The Contingencies of Corruption in Elected Public Office. Behavior and Social Issues, 8, 1-8.

Graaf, G. D. (2007). Causes of Corruption: Towards a Contextual Theory of Corruption. Public Administration Quarterly, 31(1/2 Spring), 39-86.

Graphic.com. (2015, January 29). Dr Ametewee defrauds NHIA of GH $₫ 415,000$. Retrieved from http://graphic.com.gh/news/general-news/37750-dr-ametewee-defrauds-nhia-of-gh-415-000.html.

Gyimah-Boadi, E. (2004). Democratic reform in Africa: the quality of progress. Boulder, Colo.: Lynne Rienner.

Hasty, J. (2005). The pleasures of corruption: Desire and discipline in Ghanaian political culture. Cultural Anthropology, 20(2), 271-301.

Hayes, S. C., Barnes-Holmes, D., \& Roche, B. (2003). Behavior analysis, relational frame theory, and the challenge of human language and cognition: A reply to the commentaries on relational frame theory: A post-skinnerian account of human language and cognition. Analysis of Verbal Behavior, 19, 39 - 54.

Henig, D. (2013, July 13). Stinking fish and coffee: The language of corruption. BBC News Magazine. Retrieved from http://www.bbc.co.uk/news/magazine-23227391.

ISSER. (2011). The State of the Ghanaian Economy 2010. In I. I. o. S. S. a. E. Research). (Ed.). Accra: University of Ghana.

Johnston, J. (1972). Punishment of human behavior American Psychologist, 27(11), 1033-1054 doi: http://dx.doi.org/10.1037/h0033887.

Klitgaard, R. E. (1988). Controlling corruption. Berkeley, Calif.: University of California Press.

Knowles, M., \& Moon, R. (2006). Introducing Metaphor. London; New York: Routledge.

LeVine, V. (1975). Political Corruption: The Ghana Case. Stanford, CA: Hoover Institution.

Lewis, M. (2000). Who is paying for health care in Eastern Europe and Central Asia? A paper prepared for the Human Development Sector Unit, Europe and Central Asia Region. Washington, D.C. World Bank: 1-30.

Luke, N. M. (2003). Analysis of poetic literature using B. F. Skinner's theoretical framework from verbal behavior Analysis of Verbal Behavior, 19, 107 - 114.

Luo, Y. (2004 ). An Organizational Perspective of Corruption Management and Organization Review, 1:1, 119-154. doi: $10.1111 / \mathrm{j} .1740-8784.2004 .00006 . \mathrm{x}$

Metaphor. (n.d.). www.oxforddictionaries.com. Metaphor definition. Retrieved from http://www.oxforddictionaries.com/definition/english/metaphor.

Mbiti, J. (2002) The African proverbs project and after Vol. 1. Lexikos 12.

Mowrer, O. H. (1956). Two-factor learning theory reconsidered, with special reference to secondary reinforcement and the concept of habit. Psychological Review, 63(2), 114 - 128. doi: http://dx.doi.org/10.1037/h0040613.

Noonan, J. T., Jr. (1984). Bribes. New York: Macmillan.

Palmer, D. C. (1991). A behavioral interpretation of memory In S. C. Hayes \& P. N. Chase (Eds.), Dialogues on Verbal Behavior (pp. 261-279). Reno: Context Press. 


\section{VERBAL OPERANTS OF CORRUPTION}

Patrick, C. (Producer). (2013, July 12). The Language of Corruption, from Cash for Soup to Nokia Box. Retrieved from http://patrickcox.wordpress.com/2013/07/16/the-language-of-corruption-from-cash-for-soup-to-nokiabox/.

Petursdottir, A. I. (2013). Editorial: Verbal behavior and motivating operations. The Analysis of Verbal Behavior, 29(1), $1-2$.

Polzenhagen, F., \& Wolf, H.-G. (2007). Culture-specific conceptualisations of corruption in African English. Linguistic analyses and pragmatic applications. In F. Sharifian \& G. B. Palmer (Eds.), Apllied Cultural Linguistics. Amsterdam/Philadelphia: John Benjamins Publishing Company.

Rabl, T. (2008). Private corruption and its actors: Insights into the subjective decision making processes. GroßUmstadt: Pabst Science Publishers,.

Rose-Ackerman, S. (1999). Bribes, patronage, and gift giving. Corruption and government: causes, consequences, and refrom. Cambridge: Cambridge University Press.

Seekins, T., Fawcett, S. B., Cohen, S. H., Elder, J. P., Jason, L. A., Schnelle, J. F., \& Winett, R. A. (1988). Experimental evaluation of public policy: the case of state legislation for child passenger safety Journal of Applied Behavior Analysis, 21(3), 233-243. doi: 10.1901/jaba.1988.21-233.

Sidman, M. (1960). Tactics of Scientific Research: Evaluating Experimental Data in Psychology. New York: Basic Books.

Skinner, B. F. (1945). The operational analysis of psychological terms. Psychological Review, 52, 278 - 294.

Skinner, B. F. (1957). Verbal Behavior. Englewood Cliffs: Printice-Hall.

Swamy, A., Azfar, O., \& Lee, Y. (2001). The Causes and Consequences of Corruption. Annals of the American Academy of Political and Social Science, 573(2001), 42-56.

TI. (2013). Corruption by country - Ghana. http://www.transparency.org/country\#GHA.

TI. (2014). Corruption by country - Ghana. http://www.transparency.org/country\#GHA.

Treisman, D. (2000). The Causes of Corruption: A Cross-National Study Journal of Public Economics, 76(3), 399457.

Vian, T., Gryboski, K., Sinoimeri, Z., \& Clifford, R. H. (2004). Informal Payments in the Public Health Sector in Albania: A Qualitative Study. Retrieved from http://www.healthsystems2020.org/content/resource/detail/1612/.

Williams, M., Thyer, B. A., Bailey, J. S., \& Harrison, D. F. (1989). Promoting safety belt use with traffic signs and prompters Journal of Applied Behavior Analysis, 22(1), 71-76. doi: 10.1901/jaba.1989.22-71.

Wilson, J. Q., \& Herrnstein, R. J. (1986). Crime \& human nature: The definitive study of the causes of crime. New York: Simon \& Schuster.

Wittink, J. (2011). Reliable Metaphor Analysis in Organizational Research. Towards a dual, dynamic approach. Retrieved from http://dare.ubvu.vu.nl/handle/1871/25612.

Yankah, K. (2012). The proverb in the context of Akan rhetoric: Diasporic Africa Press. 